体育学研究, $35: 53-61,1990$.

\title{
ハードル走における踏切時間を短縮する要因
}

\author{
山田憲 政1) 宮下㥶
}

\section{Factors reducing the takeoff time in hurdling}

\author{
Norimasa Yamada ${ }^{1}$ and Ken Miyashita ${ }^{2}$
}

\begin{abstract}
The purpose of this paper was to obtain the basic data necessary for studying the technique to reduce the takeoff time in hurdling. For our experimental subjects, we used two of Japan's top class hurdlers. We analyzed the center of gravity (CG) height from the touchdown point of the last stride to the point of toe-off on the takeoff, and the vertical reaction forces of the support phase of the last stride and the takeoff phase.

The results were summarized as follows;

1) The vertical velocity of the $C G$ of the last stride was $0.35 \mathrm{~m} / \mathrm{s}$ or $45 \%$ less in the toe-off compared to the touchdown. Thus, reducing the vertical velocity of the toe-off of the last stride and the CG height of the airborne phase of the last stride would lead to a reduction in the vertical momentum of the body in the touchdown, and was therefore effecitve in reducing the takeoff time.

2) The vertical momentum at touchdown was smaller than that of the last stride, but the initial peak of the vertical reaction force was 1.9 times greater. This force was effecitve in reducing the vertical momentum of the body at touchdown in a short time, and was therefore considered to be an important factor for reducing the takeoff time.
\end{abstract}

(Japan J. Phys. Educ., 35: 53-61, June, 1990.)

\section{綪}

はじめに，本研究で用いるハードル走の用語 の定義をスティック図を用いて図 1に示す。 ハードル走が走と異なる点の 1 つとして， ハードルを越えるために身体重心（CG）を少な くともハードルより高く上昇させなければなら ないことが挙げられる。そのために，ハードル 走における踏切の離地時の CG の鉛直方向の速 度は，走の離地時のそれよりも大きい必要があ る。桶ロら ${ }^{73,8)}$ は, ハードル走の踏切動作を力学 的に分析し「踏切局面においてはハードルを越 すために身体重心を積極的に上方に移動させて いる.」と報告している。
Mann and Herman ${ }^{14)}$ は，ロサンゼルスオリ ンピック（1984年）の女子 $100 \mathrm{~m}$ ハードルの決勝 時のハードラーの動作を分析し，踏切時間が短 いことが優れたハードラーの 1 つの要因である ことを報告している。しかし，この踏切時間を 短縮する要因を明らかにした研究は見当たらな い.

走り高跳びや走り幅跳びの踏切に咸する研究 では，踏切局面ばかりでなく，踏切に至るまで の準備局面の重要性が報告されている ${ }^{13,6) か ゙ ， ~}$ ハードル走の踏切においても，短時間で走より 高い鉛直方向速度を得るために有利になるよう な準備局面があると考えられる，陸上竸技の指 尊書 ${ }^{101}$ には八ードル間疾走について「第一步目
1) 北海道大学教育学部 干060 札幌市北区北11条西 7 丁目

2) 筑波大学体育科学系 干305つくば市天王台 1- 1-1
1. Faculty of Education, Hokkaido University, Sapporo-City, Hokkaido (060),

2. Institute of Health and Sports Sciences, University of Tsukuba, Tsukuba city, Ibaraki (305) 

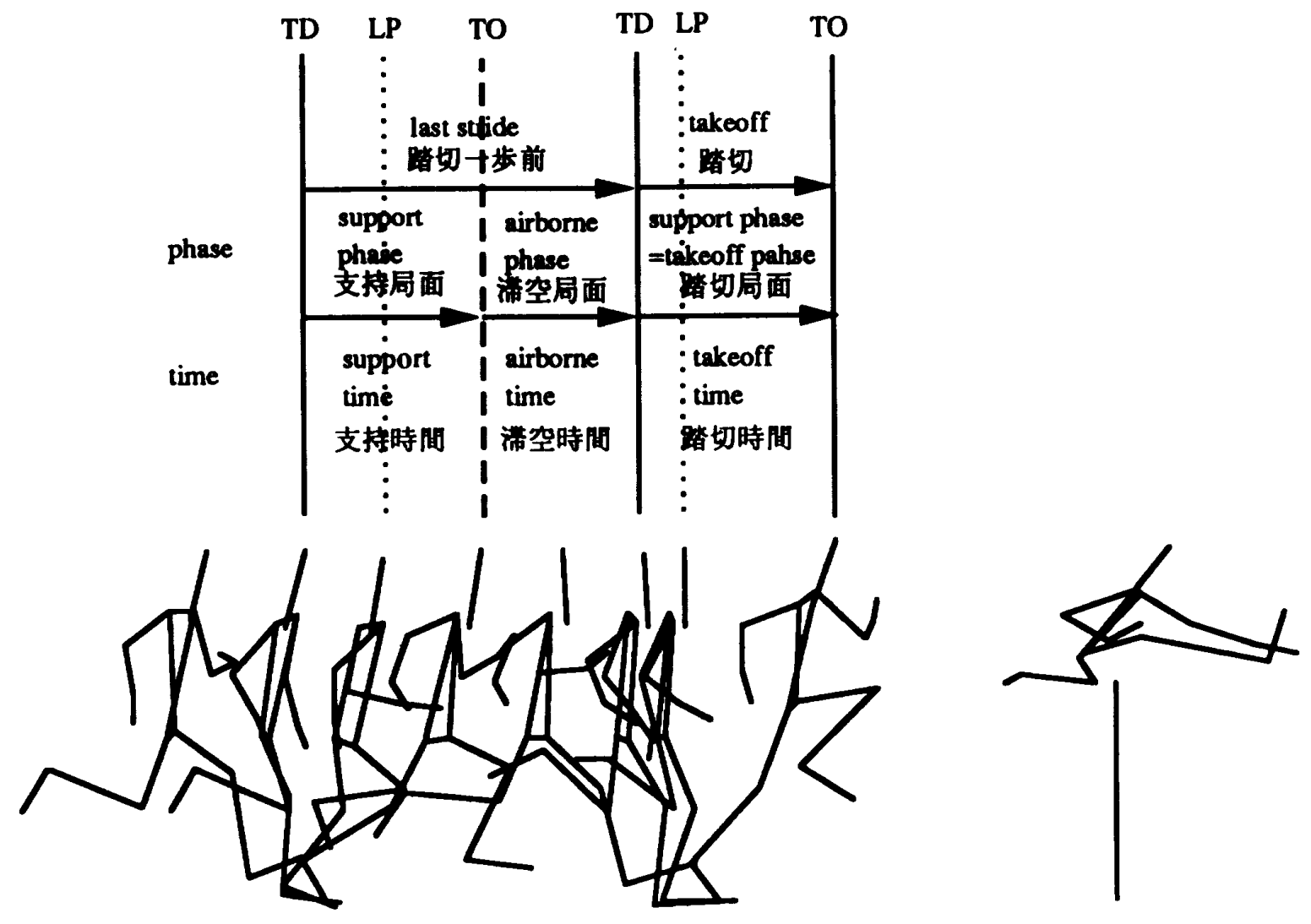

TD(Touch down) : first instant of contact of the support foot with ground（若地時） TO(Toe-off ) : last instant of contact of the support foot with ground (地時) LP(Lowest point): Lowest point of CG height during the support phase

Fig. 1 Definitions of the hurdling terms

はハードル間疾走のリズムを生み出すととすに 一定の速度を維持する。踏切一歩前では生み出 されたリズムをある程度調節する.」と，踏切一 歩前の重要性が述べられている，どのようにリ ズムを調節するかについては記されていない が,この調節は次の踏切に有利になるように行 なわれると推察される。また，磯と石井"11のハー ドル間疾走中の CGの上下動のデータる，踏切 一歩前では踏切二歩前と比較して CG の上下動 が減少することを示している。

本研究の目的は，ハードル走の踏切時間を短 縮する技術を究明するための基礎資料を得るこ とであり，日本国内のトップレベルのハード ラ一の踏切一歩前の着地時から踏切の離地時ま での CG の上下動，および踏切一歩前の支持局 面之踏切局面の地面反力の鉛直成分の分析を行
なった。

万法

\section{1. 实殹方法}

\section{1-1. 被耠者}

被験者は $110 \mathrm{~m}$ ハードルの日本国内のトップ レベルのハードラー 2 名を用いた。 このうちの 1 人は $110 \mathrm{~m}$ ハードルの手動日本記録保持者で ある、被験者の身体特性および110m ハードル の最高タイムを表 1 に示した。

\section{1-2. 実験の装置と条件}

本研究では, 図 2 に示した条件で55mハード ル走を全力で行なわせた４台目のハードルの 踏切一歩前と，踏切における地面反力をキス ラー社製 Force plateを用いて測定するととも に, 2 台の $16 \mathrm{~mm}$ 高速カメラ(Photo Sonic 1PL, 

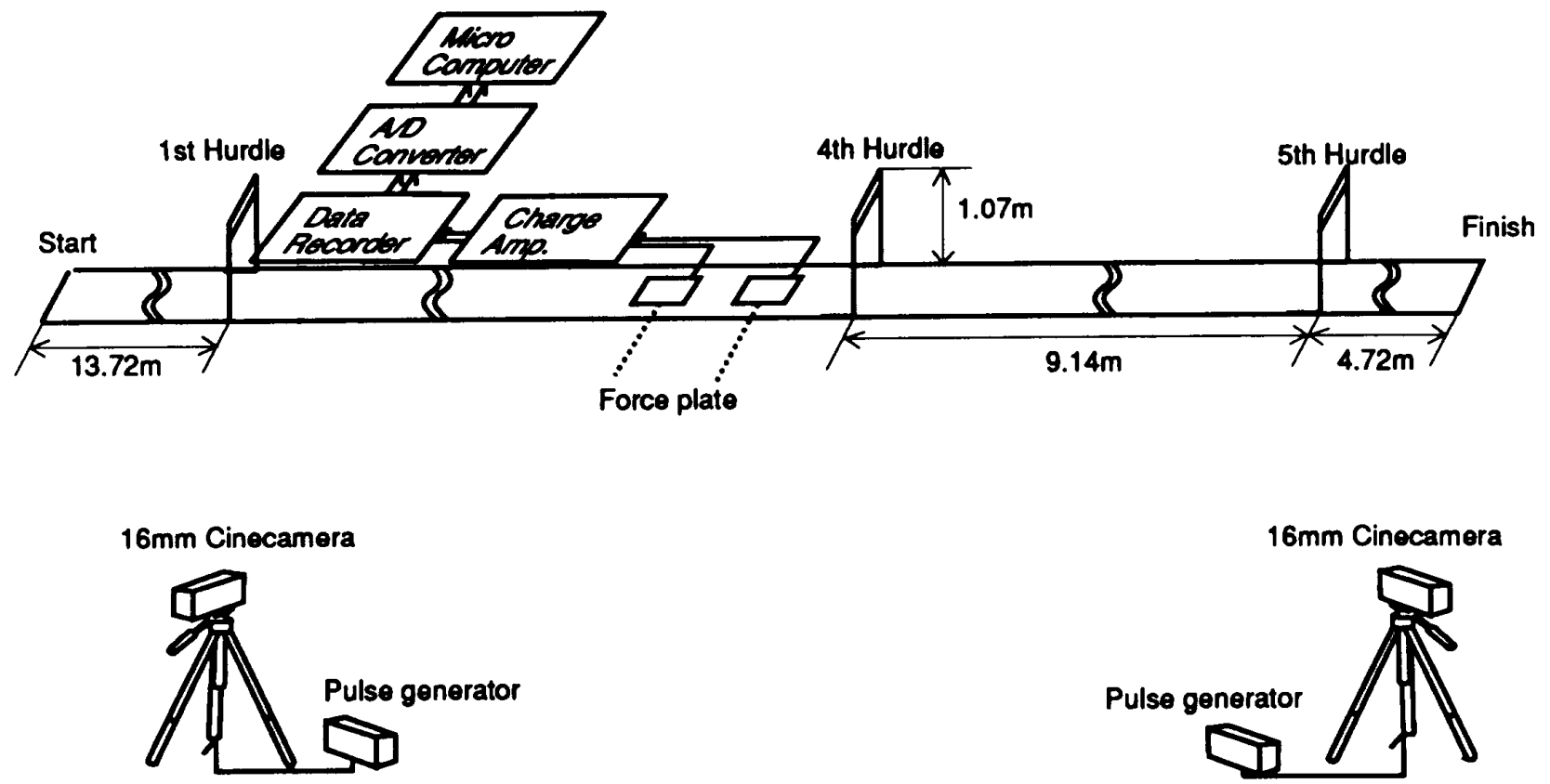

Fig. 2. Construction of experimental instruments

Table 1. Characteristics of subjects

\begin{tabular}{cccc}
\hline Subject & $\begin{array}{c}\text { Height } \\
(\mathrm{m})\end{array}$ & $\begin{array}{c}\text { Mass } \\
(\mathrm{kg})\end{array}$ & $\begin{array}{c}\text { Best record } \\
(\mathrm{s})\end{array}$ \\
\hline $\mathrm{S}$ & 1.80 & 70.0 & 13.9 \\
$\mathrm{~W}$ & 1.77 & 68.0 & 14.2 \\
\hline
\end{tabular}

Milliken DBM-5D）を用いてこの笔囲の動作を 撮影した。この時の撮影コマ数は，パルスジ ネレータからの電気信号 $(100 \mathrm{~Hz})$ をフィルムに 写し込むことによって算出したが，それぞれ毎 秒126コマ, 125コマであった。

force plateを用いて運動中の足に作用する 外力を測定する場合, force plate を踏まなかっ たり，無理に force plate を踏んだ試技は分析に 用いられないため，自然なフォームで force plateを踏むまで試技を綝り返し行ならのが一 般的である ${ }^{13), 20)}$. しかし，ハードル走の場合は ハードル間の距離があらかじめ決定しており， その間を 3 歩で走るため，ほぼハードルに対し て足の接地する位置が決定する。よって，本研 究では試合の時と同様に, force plate を踏むこ とを意識させずに全力で 5 台のハードルを走り きらせたが，2 2 人の被験者とも 1 回で 2 台の force plateを自然なフォームで踏むことがで
きた。

DLT 法19)用いて 2 台のカメラから得られ る 2 次元座標から 3 次元座標を得るため, あら かじめ摄影簀冊内の 9 简所 (45点)に校正器 (直 径 $5 \mathrm{~cm}$ の白い玉が50cm 間隔で 5 個綎につな がったもの）を設置し，2台のカメラに写し込 んた。

\section{2. 分析方法}

2 台のカメラで撮影した 2 人の被験者のフィ ルムは、 コマ毎に23点の身体の各分析点および ハードルの各コーナーの 4 点の計 27 点の座標を ディシタイザーにより読み取り，マイクロコン ピュータに入力した。 2 台のカメラから得られ た27点の 2 次元座標は, 踏切の着地時のコマを 基準に120fps のサンプリングで 3 次スプライ ン成数を用いて補間した。このようにして，2 台のカメラから得られた 27 点の 2 次元座標を同 期させ DLT 法を用いて 3 次元座標を得た。 3 次元座標はバタワース型ディジタルフィルタを 用いて $10 \mathrm{~Hz}$ の遮断周波数で平滑化した。なお， 校正点の座標值の実際の值と,DLT 法で算出し た校正点の座標値の最大誤差そして標淮誤差は それぞれ, 前後方向で0.04と0.0016m, 左右方向 で0.042と0.0016m, 上下方向で0.013と0.003m 


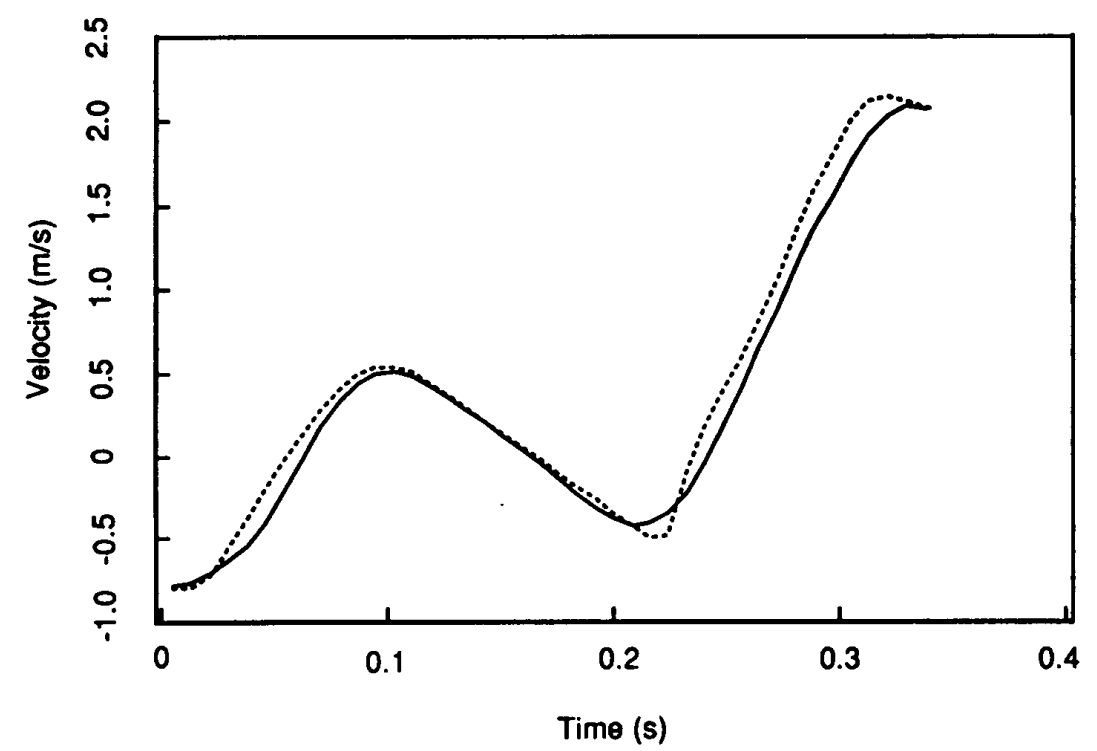

Fig. 3. Vertical velocity for subject $S$ from touchdown of the last stride to toe-off of the takeoff. Solid line represents velocity from film data and broken line represents velocity calculated using force data.

であった。各被悇者の身体重心位膡は，Chandler et al.5)の値を用いて算出した。

地面反力のデータは A/D 変換器を介し、サ ンプリングタム $5 \mathrm{~ms}$ でディジル化し，マイ クロコンピュータに取り込んだ。

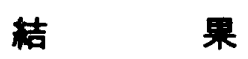

\section{CGの锄亩方向速度について}

CG の鉛直方向速度は，フィルム分析から得 られる座標值を数値微分して求める方法と，地 面反力を用いて以下の式によって算出する方法 が考えられる。

$\mathrm{V}_{\mathrm{yi}}=\mathrm{V}_{\mathrm{y} 0}+\frac{1}{\mathrm{~m}} \int_{0}^{\mathrm{i}}(\mathrm{Fyi}-\mathrm{mg}) \mathrm{dt}$

ここで, Vyi は時間 $\mathrm{i} に$ における垂直方向の CG の速度で, $\mathrm{i}=0$ が着地時であり Vy0はフィルム 分析から得る必要がある。 $\mathrm{m}$ は被験者の身体質 量, $\mathrm{g}$ は重力加速度, Fyi は時間 $\mathrm{i} に$ における地面 反力の鉛直成分である. 図 3 に被験者 $\mathrm{S}$ のフィ ルム分析から得られた CG の鉛直方向速度（実 線）と，地面反力を用いて(1)式から算出した CG の鉛直方向速度 (波線)の踏切一歩前の着地 時から踏切までの時間的変化を示す，2つの波 形は，振幅，位相，そして極値とも非常に類似
している. 本研究では，(1)式から算出した速度 を用いることにした。

\section{2. 敘西方向地面反力と CG の上下峌}

図 4 に被験者 $\mathrm{S} の$ 踏切一歩前の着地時から 踏切の離地時までの CG の高さと(波線)，その 間に足に作用する地面反力の鉛直成分（実線） の時間的変化を示す。この 2 つの波形は時間的 に同期されて示されている，CGの波形上に示 されている 1 から 7 までの数字の 1 から 3 は, 踏切一歩前の着地時(TD), CG が最も下降した 瞬間 (LP)，離地時（TO）を示しており，同様 に，5から 7 は踏切における TD, LP, TO を示 している.また， 4 は踏切一歩前の滞空中の CG が最も上昇した瞬間 (HP) を表している。これ らの各数字に示されるポイントに対応したス ティック図を図の上に示した。同様に，被験者 $\mathrm{W}$ については図 5 に示した。 また，踏切一歩前 の支持時間と TDから LP およびLPから TO までの時間，支持時間に対する割合，そしてそ れらの間の CG の鉛直方向の変位をまとめたの が表 2 である. 踏切一歩前では 2 人の被験者と む TD-LPょりも LP-TOの時間そしてCGの 変位ともにやや大きい値を示した。これに対し 踏切では, TD-LP の支持時間に対する割合は被 

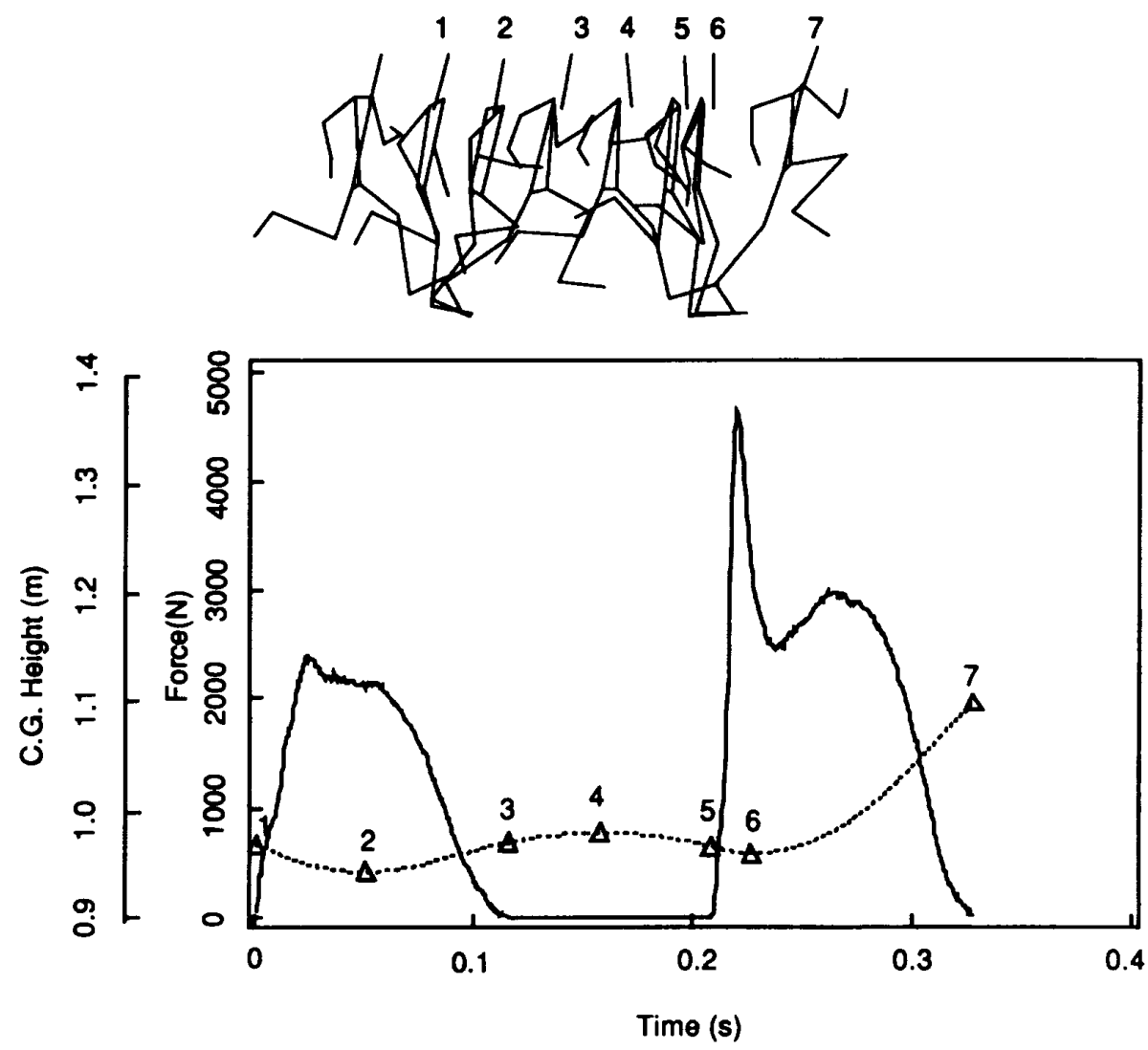

Fig. 4. Vertical reaction forces during support phases of the last stride and takeoff (-), and CG height from touchdown of the last stride to toe-off of the takeoff $(\cdots \cdots)$ for subject $S$. The numbers along the broken line represent the following: 1. Touchdown of the last stride 2. Lowest point of CG height during the last stride 3 . Toe-off of the last stride 4. Highest point of CG height during airborne phase of the last stride 5. Touchdown of the takeoff 6. Lowest point of CG height during the takeoff 7. Toe-off of the takeoff

Table 2. Support times and CG displacements during the last stride and during the takeoff

\begin{tabular}{|c|c|c|c|c|c|c|c|c|}
\hline \multirow{2}{*}{ Subject } & & & \multicolumn{3}{|c|}{ Last stride } & \multicolumn{3}{|c|}{ Takeoff } \\
\hline & & & TD-LP & LP.TO & TD-TO & TD-LP & LP-TO & TD-TO \\
\hline \multirow{3}{*}{$S$} & Time & (s) & 0.051 & 0.066 & 0.116 & 0.019 & 0.101 & 0.119 \\
\hline & Time & (\%) & 43.530 & 56.470 & 100.000 & 15.550 & 84.450 & 100.000 \\
\hline & Dis. & $(\mathrm{m})$ & -0.025 & 0.027 & 0.002 & -0.006 & 0.137 & 0.131 \\
\hline \multirow{3}{*}{ W } & Time & (s) & 0.053 & 0.077 & 0.130 & 0.016 & 0.123 & 0.139 \\
\hline & Time & (\%) & 40.540 & 59.460 & 100.000 & 11.510 & 88.490 & 100.000 \\
\hline & Dis. & $(\mathrm{m})$ & -0.024 & 0.038 & 0.014 & -0.004 & 0.187 & 0.183 \\
\hline
\end{tabular}

TD : touchdown, LP : lowest point of CG height, TO : Toe-off

験者 S で15.55\%，Wで11.51\%と非常に少な く，この間の CG の变位すそれぞれ LP-TO間 の $1 / 20,1 / 46$ と非常に小さい。踏切一歩前と踏
切での支持時間は 2 人の被耠者ともほほ等しい 值を示したことから，踏切では踏切一歩前と比 較して, CGの下降時間および下降距離が減少 

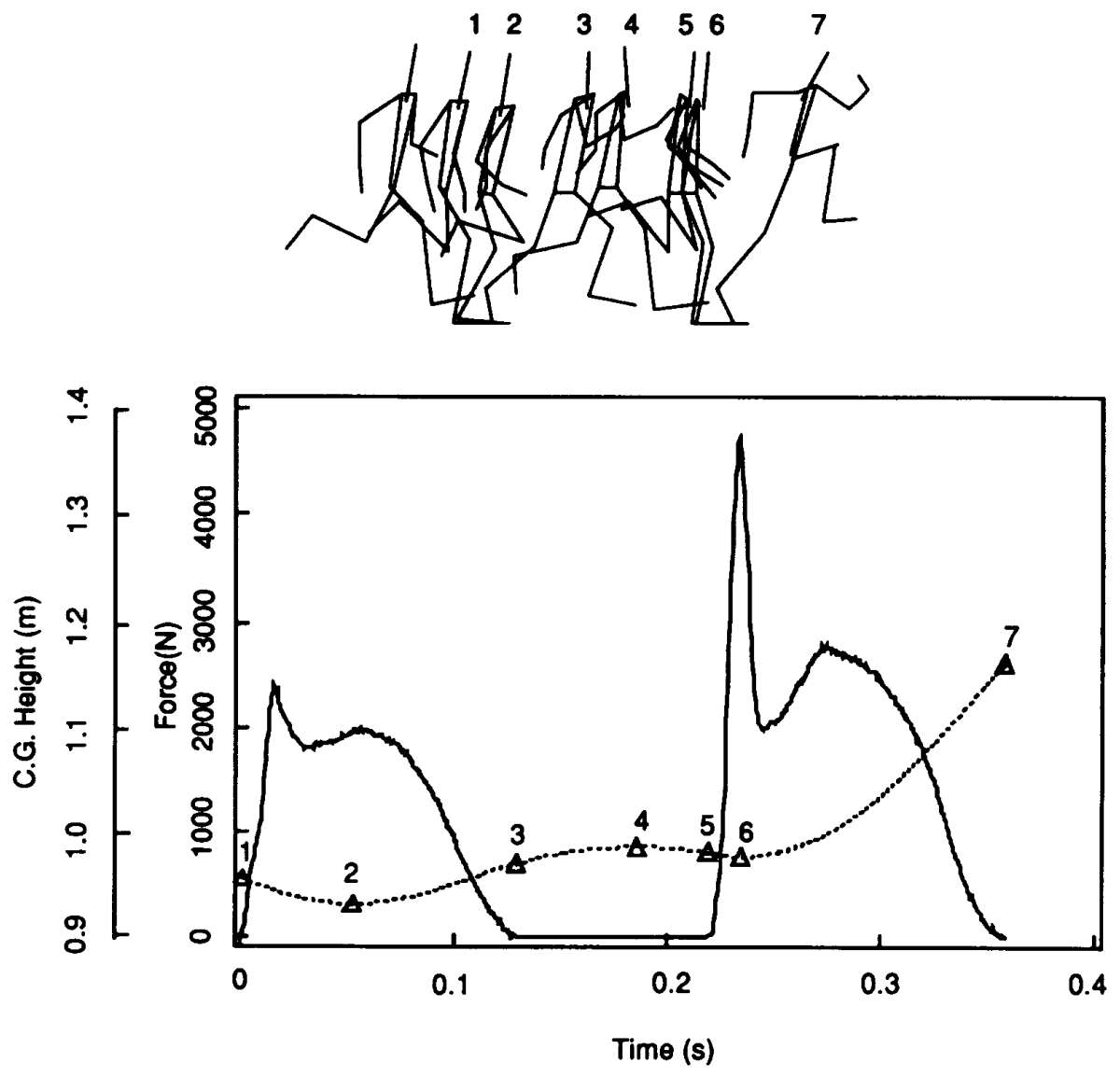

Fig. 5. Vertical reaction forces during support phases of the last stride and takeoff ( - ), and CG height from touchdown of the last stride to toe-off of the takeoff $(\cdots \cdots)$ for subject $\mathrm{W}$. The numbers along the broken line represent the following: 1 . Touchdown of the last stride 2. Lowest point of CG height during the last stride 3. Toe-off of the last stride 4. Highest point of CG height during airborne phase of the last stride 5. Touchdown of the takeoff 6. Lowest point of CG height during the takeoff 7. Toe-off of the takeoff

Table 3. Vertical velocities of CG and vertical momentums of the whole body at touchdown and toe-off of the last stride and the takeoff

\begin{tabular}{cllrrrrr}
\hline \multirow{2}{*}{ Subject } & & \multicolumn{2}{c}{ Last stride } & & \multicolumn{2}{c}{ Takeoff } \\
\cline { 3 - 4 } \cline { 7 - 8 } & & \multicolumn{1}{c}{ TD } & \multicolumn{1}{c}{ TO } & \multicolumn{1}{c}{ TD } & \multicolumn{1}{c}{ TO } \\
\hline \multirow{2}{*}{$\mathrm{S}$} & Velocity & $(\mathrm{m} / \mathrm{s}$ & -0.78 & 0.43 & & -0.49 & 2.05 \\
& Momentum & $(\mathrm{kg} \cdot \mathrm{m} / \mathrm{s})$ & -54.60 & 30.10 & & -34.30 & 143.50 \\
$\mathrm{~W}$ & Velocity & $(\mathrm{m} / \mathrm{s}$ & -0.78 & 0.47 & & -0.43 & 2.29 \\
& Momentum & $(\mathrm{kg} \cdot \mathrm{m} / \mathrm{s})$ & -53.04 & 31.96 & & -29.10 & 155.72 \\
\hline
\end{tabular}

TD : touchdown, TO : toe-off

し，CG の上昇の占める割合が大きいといえる. 力波形は，走運動における地面反力の報告と 同様 2 つのビークをるつ二蜂性の波形3),15),16),18) を示した. 2 人の被験者とも踏切一步前に対し
踏切での地面反力は，第一のビークでは約 1.9 倍，第 2 のピークでは約1.3倍の值を示した。

\section{3. 鉛冝方向の速度・五動息}

表 3 に踏切一歩前と踏切に打ける着地時と離 
地時の鉛直方向の速度と運動量を示す。上方の 速度を正としている，踏切では，離地時の速度 の絶対値は着地時に対して, 被験者 $\mathrm{S}$ では約 4 倍, 被験者 Wでは約 5 倍の值を示し増加した のに対し，踏切一歩前では被殹者 S では約 0.55 倍, W では約0.6倍の值を示し減少した。

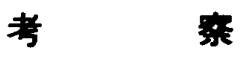

\section{2 人の被験者のデータからの考寀につい} $\tau$

本研究で用いた被験者は日本トップクラスの ハードラー 2 人である。得られる結果は競技レ ベル，身体の解剖学的特性等によって変わって くると考えられる。しかし，ハードル走の踏切 時間短縮という本研究の目的からデータを眺め た場合， 2 人の被験者ともに共通する結果のみ で，相反する結果は得られず踏切の目的に添 らあのであった。よって，本研究で得られた 結果は八ードル走の踏切における上級ハード ラーの共通の特徵であると考えて良いと判断 した。

\section{2. 跂切時間を短綰する要因について}

走およびハードル走ではそのパフォーマンス は水平方向の速度で競われる。よって，いかに 水平方向の速度を落とさないようにハードルを 超えるかがハードル走のパフォーマンスを決定 する主な要因となる。ここで，滞空局面が含ま れる人の移動様式である走は，小さな跳躍の連 続と考えることができ2)，その意味では，1歩 1 歩の跳䠰の中で重力に対して身体の位置エネル ギーを変動させることが走運動の 1 つの本質で あると考えられる，よって，走行中に八ードル を飛び越えるハードル走では，CGの上下動を 分析することがその運動の本質を追及する $1 つ$ の重要な方法であると考えられる。

連続した跳躍では下降する運動量を一旦 0 と して，再び上昇する運動量を得る必要がある。 従って，地面反力の鉛直成分は，身体の重量に 対してと，身体の鉛直方向運動量を変化させる ために作用される。よって，踏切時間を短くす るには次の 3 つの条件が考えられる。
1）着地時の鉛直方向の運動量を小さくする.

2）短時間に下降の運動量を 0 とする.

3）短時間にハードルを超えるために必要な 上昇の運動量を得る。

1）については，踏切の一步前で決定されるこ とから，このことは踏切時間短縮の準備動作と 考えられる，走運動中の着地時と離地時の鉛直 方向速度の大きさはほぼ等しい値を示す4のに 対し，本研究で用いた 2 人の被験者ともにハー ドル走での踏切一歩前では離地時の方が着地時 より約 $0.35 \mathrm{~m} / \mathrm{s}$, 割合にして約 $45 \%$ 少ない値を 示した. その結果, 踏切一歩前の滞空中の CGの 上昇距離も减少し, 踏切の着地時の鉛直方向の 速度・運動量を小さくすることになる。

このよ5に，踏切一歩前の離地時の鉛直方向 速度を小さくし, 踏切一歩前の滞空局面の CG の上昇距離を小さくすることは，踏切における 着地時の身体の鉛直方向運動量を减少させるこ とにつながり，踏切時間を短縮するために効果 的であると考えられる。

2)については，運動量を短時間に0にするた めには，短時間に大きな力が作用する必要があ る.そのためには，踏切の着地直後に見られる 大きな衡撃力は有効であると考えられる。 Munro et al. ${ }^{16)}$ は, 各種走速度における地面反 力を測定し, 走速度の增加に伴い, 着地中の鉛 直方向の速度変化其の增加之, 着地直後の衙撃 力の鉛直成分の増加を報告している。この結果 は, 走運動における着地時と離地時の鉛直方向 の速度の大きさがほぼ等しいことから, 走速度 の増加に伴い, 着地時の鉛直方向の速度・運動 量が増加し, 着地直後の衡撃力が増加すると言 い換えることができる、しかし，本研究で用い た 2 人の被験者とすに，着地時の運動量が踏切 より踏切一歩前の方が大きいのに対し（被験者 $\mathrm{S}$ で1.6倍, 被験者 $\mathrm{W} て ゙ 1.8$ 倍), 着地直後に見ら れる地面反力の第一ビークは踏切の方が踏切一 歩前より大きくなり（2 人の被絤者とるに1.9 倍), 着地時の鉛直方向運動量が増すと着地直後 の衝撃力す增すという結果と逆の結果を示し た。このことは, ハードル走の踏切においては 
Table 4. Impulses, operation times, and mean forces in the decreasing and increasing phases of the vertical momentum of the whole body during the last stride and during the takeoff

\begin{tabular}{clrrrrrr}
\hline \multirow{2}{*}{ Subject } & & \multicolumn{2}{c}{ Last stride } & & \multicolumn{2}{c}{ Takeoff } \\
\cline { 8 - 8 } \cline { 7 - 8 } & & \multicolumn{1}{c}{ VMDP } & \multicolumn{1}{c}{ VMIP } & & VMDP & \multicolumn{1}{c}{ VMIP } \\
\hline S & Impulse & $(\mathrm{N} \cdot \mathrm{s})$ & 54.600 & 30.100 & & 34.300 & 143.500 \\
& Time & $(\mathrm{s})$ & 0.051 & 0.066 & & 0.019 & 0.101 \\
& Mean force $(\mathrm{N})$ & 1081.188 & 459.542 & & 1854.054 & 1427.861 \\
$\mathrm{~W}$ & Impulse & $(\mathrm{N} \cdot \mathrm{s})$ & 53.040 & 31.960 & & 29.100 & 155.720 \\
& Time & $(\mathrm{s})$ & 0.053 & 0.077 & & 0.016 & 0.123 \\
& Mean force $(\mathrm{N})$ & 1010.286 & 415.065 & & 1818.750 & 1266.016 \\
\hline
\end{tabular}

VMDP : decreasing phase of the vertical momentum of the whole body

VMIP : increasing phase of the vertical momentum of the whole body

いかに短時間で下降の運動量を０にすることが 重要であるかを示唆しているるのと言える。ど のよらにしたら踏切の着地時に大きな衙撃力が 生じ，着地時の鉛直方向運動量をいち早く 0 に することが可能かについては，本研究の分析方 法から得られる結果からでは言及することはで きないが，着地時の緩衙動作が主に足関節と䐂 関節で行なわれている17)とから，着地時にこ れらの関節による䜌衡動作を余り行なわないこ とが着地直後の行撃力を大きくする技術である と考党られる。串間 ${ }^{13)}$ は，Diasenta の提唱した ハードル走の踏切技術である Griffe 動作（踏切 局面の着地時に滕闺節をほぼ伸展させたままで 着地するといら動作特徽を持つ9)）を大学陸上 競技部員 3 名に対し行なわせたところ,「踏切脚 接地中の身体重心を，早期に鉛直方向に引き上 げることができた」と報告しているが，このこ とは，本研究の結果を実践的に复付けているす のと言える。

3については，鉛直方向の運動量が 0 となっ た後，ハードルを超えるために上昇の運動量を いち早く得する必要がある，鉛直方向の地面 反力を，鉛直方向運動量が 0 になるまでの局面 (VMD 局面) と，その後離地するまで運動量が 再び増加する局面 (VMI 局面)に分け，この局 面の身体重量を差し引いた平均力を次式で算出 した。
$\overline{\mathrm{F} V M D}=\int_{0}^{\mathrm{t}_{1}}(\mathrm{Fyi}-\mathrm{mg}) \mathrm{dt} / \mathrm{t}_{1}$

$\overline{\mathrm{F}} \mathrm{VMI}=\int_{\mathrm{t}_{1}}^{\mathrm{t}_{2}}(\mathrm{Fyi}-\mathrm{mg}) \mathrm{dt} /\left(\mathrm{t}_{2}-\mathrm{t}_{1}\right)$

ここで， F VMD $_{\text {VMD }}$ 局面での平均の力, $\bar{F}_{\mathrm{VMI}}$ はVMI 局面での平均の力，そして着地時 を 0 とし, $\mathrm{t}_{1}$ が鉛直方向の速度が 0 となる時間, $\mathrm{t}_{2}$ が離地の時間である。その結果を表 4 に示し た。踏切の VMI 局面では 2 人の被験者とも踏 切一歩前の約 3 倍の平均力を示し，作用時間。 約1.5倍を示した.この局面では, $1000 \mathrm{~N}$ 以上の 力を踏切の接地時間の約 $80 \%$ の時間作用させて ハードルを超えるための鉛直方向の運動量を得 ている。これらのことから，踏切一步前と踏切 では支持時間がほほ等しいが，踏切では踏切一 歩前と比較して，VMDの局面の時間を減少さ せることにより VMI 局面の時間を増加させ， 且つ, VMI 局面に作用する力も増加させる必要 がある，しかし，走り高跳びなどとは異なり， できるだけ大きい䧺地時の鉛直方向速度を得る ことが目的ではなく，むしろハードルを超える ために心要最小限の鉛直方向速度を得ることが 目的であり，よって，この局面では大きな力を 作用させるばかりではなく，その力の大きさと 作用時間を調整する能力も必要となってくると 考えられる。 


\section{要約}

本研究は，ハードル走の踏切時間を短縮する 技術を究明するための基礎資料を得るために， 2 名の国内トップレベルのハードラ一を用い, 踏切一歩前の着地時から踏切の離地時までの CG 高，扣よび踏切一歩前の支持局面と踏切局 面の地面反力の鉛直成分を分析した。得られた 結果は以下のとおりである。

1）踏切一歩前の CG の鉛直方向速度は, 離地 時の方が着地時より約 $0.35 \mathrm{~m} / \mathrm{s}$, 割合にして約 45\%少ない值を示した。このように，踏切一歩 前の離地時の鉛直方向速度を小さくし，踏切一 歩前の滞空局面の CG の上昇距離を小さくする ことは，踏切に打ける着地時の身体の鉛直方向 運動量を减少させることにつながり，踏切時間 を短縮するために効果的であると考えられた。

2）踏切の着地時の鉛直方向運動量は踏切一 歩前のそれより小さいが，着地直後に生じる鉛 直方向の衝撃力は約 1.9 倍の值を示した。この大 きな衝撃力は，着地時に身体の持つ鉛直方向の 運動量を短時間に减少させることに対して有効 であることから, 踏切時間短縮の重要な要因で あると考えられた。

\section{引用・言考文献}

1) Ae, M., Sakatani, Y., Yokoi, T., Hashiwara, Y. and Shibukawa, K., "Biomechanical analysis of the preparatory motion for takeoff in the Fosbury flop," Int. J. Sport Biomechanics, $2: 66-77,1986$.

2）フレキサンダー(平本幸男訳)，バイオメカニクス， 粪談社, 1976. pp. 49-56.

3) Bates, B.T., James, S.L., Oslerning, L.R. and Sawhill, J.A., "Effects of running on ground reaction force," in Morecki, A., Fiedelus, K., Kedzior, K. and Wit, A. (Eds.), Biomechanics, VII-B, University Park Press: Baltimore, 1981. pp. 226 -33 .

4) Cavagna, G.A., Saibene, F.P. and Margaria, R., "Mechanical work in running," J. Appl. Physiol., 19-2 : 249-56, 1964.

5) Chandler, R.F., Clauser, C.E., McConville, J.T., Reynolds, H.M. and Young, J.W., "Investigation of inertial properties of the human body," Aerospace Medical Research Laboratory Technical
Report, Write Patterson Air Force Base : Ohio, 1975. pp. 74-137.

6) Hay, J.G., Miller, J.A. and Canterna, R.W., "The technique of elite male long jumpers," J. Biomechanics, 19-10:855-66, 1986.

7）熥口憲生・湯浅量元・松尾湩文・福永哲男「地面反 力から見たハードリンクの特性」体育の科学, 38 ： 313-17, 1984.

8）桶口電生・浅川正一・湯浅景元・斉藤昌久 - 平岡寿 弘「ハードリングの力学的分析」中京体育学研究, $23: 44-51,1982$.

9）平岡秀婎「Drut guy の走法-110mハードルー」東 海大学体育学部紀要, $7: 133-38,1977$.

10）ホメンコフ（織田幹雄・小野耕三訳），陸上競技卜 レーナー用教科書, ペースボール・マガジン社, 1978. pp. 241-42.

11）磯繁雄・石井喜八「110M 障害走の記録向上の要因 分析」日本体育学会第36回大会号, p. $620,1985$.

12）串間敦郎「ハードル走の踏切技術に成する力学的考 察」筑波大学体育科学系修士文, 1987. pp. 55-65.

13) Mann, R.V., "A kinetic analysis of sprinting," Medicine and Science in Sports and Exercise, 13 : 325-28, 1980.

14) Mann, R. and Herman, J., "Kinematic analysis of Olympic hurdle performance: Women's 100 meters," Int. J. Sport Biomechanics, 1: 163-73, 1985.

15）宮地 力・小林一敏・牛山幸彦「ランニンク中の着 地衡撃の粘弾性モデルによるシミュレーション」筑 波大学体育科学系紀要, $11: 253-63,1988$.

16) Munro, C.F., Miller, D.I. and Fuglevand, A.J., "Ground reacton forces in running: A reexamination," J. Biomechanics, 20-2:147-55, 1987.

17）永田 晨・室 增男・日丸哲也「徯行能の測定に成 する研究」体有学研究, 24-1:51-58, 1979.

18) Nigg, B.M., Denoth, J. and Neukomm, P.A., "Load on the human body," in Morecki, A., Fiedelus, K., Kedzior, K. and Wit, A. (Eds.), Biomechanics, VII-A, University Park Press: Baltimore, 1981. pp. 88-105.

19) Walton, J.S., "Close-range cine-photommetry : Another approach to motion analysis," in Terauds, J. (Ed.), Science in Biomechanics Cinematography, Academic Publishers: California, 1979. pp. 69-97.

20）山田憲政・小林一敏 - 威阱雄「走行中の下肢の運 動のフーリエ級数に上る分析」体育学研究, 31-1:67 $-76,1986$.

（平成元年11月 30 日受付） 